\title{
PERBANDINGAN MEMANDIKAN TRADISIONAL DENGAN DISPOSABLE BED BATHS DI RUANG INTENSIVE CARE UNIT (ICU)
}

\author{
Comparison Between Traditional Bathing And Disposable Bed Baths In Intensive Care \\ Unit (ICU) \\ Muhammad Yusuf ${ }^{1}$, Yuliana Syam², Andi Masyita Irwan ${ }^{3}$ \\ ${ }^{1}$ Mahasiswa Program Studi Magister Ilmu Keperawatan, Fakultas Keperawatan Universitas \\ Hasanuddin, Makassar \\ ${ }^{2,3}$ Dosen Program Studi Magister Ilmu Keperawatan, Fakultas Keperawatan Universitas \\ Hasanuddin, Makassar \\ e-mail:ahmad.yusuf1127@gmail.com
}

\begin{abstract}
ABSTRAK
Pendahuluan: Sekitar 1,75 hingga 3,5 juta pasien di rumah sakit mendapatkan infeksi nosokomial setiap tahun. Pasien di ICU yang ventilator yang dipasang secara mekanis tidak dapat memenuhi kebutuhan perawatan diri, mandi. Metode Bathing with Disposable bed baths (DBB) menggunakan lap pencuci sekali pakai dapat mengurangi waktu mandi dan menghilangkan penggunaan bak mandi yang terbukti sebagai reservoir bagi bakteri dan dapat menularkan infeksi di rumah sakit. Penelitian ini bertujuan untuk membandingkan durasi, biaya dan perbedaan jumlah mikroorganisme antara mandi tradisional dan menggunakan Disposable Bed Baths. Metode: Pencarian literatur menggunakan empat basis data: Pubmed, ProQuest, Science Direct, dan Google Scholar dengan memasukkan kata kunci mandi tradisional, Disposable bed baths, dengan akhir tahun diterbitkan pada tahun 2011 hingga 2017. Penelitian ini memperoleh 34 artikel dengan pengecualian 22 artikel. Hasil: Artikel yang relevan dengan topik adalah 12 (2 tinjauan sistematis, 1 studi deskriptif, 5 uji coba terkontrol secara acak, 4 studi kasus). Tempat penelitian pasien di ICU dan memiliki pasien lanjut usia. Beberapa penelitian menemukan bahwa kedua metode mandi dapat mengurangi jumlah mikroorganisme di kulit, mandi tradisional dapat menyebabkan kulit kering. Dalam hal biaya dan lama mandi, metode mandi dengan tempat tidur sekali pakai lebih baik daripada metode mandi tradisional. Kesimpulan: Ada sedikit penelitian tentang perbandingan mandi tradisional dan mandi sekali pakai dalam kaitannya dengan biaya, durasi dan jumlah mikroorganisme, terutama pasien yang dirawat di ICU.

Kata kunci: pemandian tradisional, pemandian tempat tidur sekali pakai, ICU.
\end{abstract}

\begin{abstract}
Introduction: Approximately 1.75 to 3.5 million patients in the hospital get nosocomial infection each year. Patients in ICU that mechanically installed ventilators is unable to meet the needs of self-care, bathing. Bathing with Disposable bed baths (DBB) method using disposable bath wash lap can reduce the time in bathing and eliminating the use of bath basin that proved as a reservoir for bacteria and can transmit infection in hospital. This study aims to compare the duration, cost and differences in the number of microorganisms between traditional bathing and using Disposable Bed Baths. Method: The literature search used four databases: Pubmed, ProQuest, Science Direct, and Google Scholar by including traditional bathing keywords, Disposable bed baths, with year-end published in 2011 to 2017. This study obtained 34 articles
\end{abstract}


with exclusions 22 articles. Result: Articles that are relevant to the topic are 12 (2 systematic review, 1 descriptive study, 5 randomized controlled trials, 4 case study). Setting of patient research in ICU and having elderly patient. Some research finds that both bathing methods can reduce the number of microorganisms in the skin, traditional bathing can cause dry skin. In terms of cost and bathing duration, bathing methods with disposable bed baths better than traditional bathing methods. Conclusions: There is little research on the comparison of traditional bathing and disposable bed baths in relation to cost, duration and number of microorganisms, especially patients treated in the ICU.

Key words : traditional bathing, disposable bed baths, ICU.

\section{PENDAHULUAN}

Infeksi nosokomial dikaitkan dengan peningkatan lama tinggal di rumah sakit, tingkat kematian dan biaya yang meningkat. Meningkatnya resiko kematian dan kecacatan pada pasien yang dirawat di Intensive Care Unit (ICU) tidak hanya diakibatkan oleh penyakit kronis tapi oleh penyebab sekunder yaitu infeksi nosokomial (Noto et al., 2015; Whiteley, Bodenham, \& Bellamy, 2006).

Setiap tahun sekitar 1,75 hingga 3,5 juta pasien yang dirawat di Rumah Sakit di Amerika Serikat, sekitar 5\% hingga 10\% diantaranya menderita infeksi nosokomial (Johnson, Lineweaver, \& Maze, 2009). Pencegahan infeksi nosokomial bisa dilakukan dengan memandikan pasien rutin untuk meningkatkan kebersihan kebersihan tubuh dan integritas kulit, yang pada gilirannya sangat penting untuk pencegahan penyakit ((Bulechek, Butcher, Dochterman, \& Wagner, 2013). Standar memandikan pasien melibatkan penggunaan baskom, sabun, air, lap, dan handuk, biasanya digunakan dalam pengaturan unit perawatan intensif, telah terbukti terkontaminasi dengan patogen nosokomial. Penelitian sebelumnya telah menunjukkan tingkat kontaminasi baskom mandi yang sangat tinggi dari $62 \%$ hingga 98\%(Marchaim et al., 2012)

Pasien-pasien di ruang ICU yang tersedasi dan terpasang ventilator mekanik, terlalu lemah untuk dapat melakukan personal hygiene sendiri (Coyer, Sullivan, Gradcert, \& Nicola Cadman, 2011). Perawat melakukan personal hygiene menggunakan baskom yang berisi air hangat, sabun dan dan washlap (Horstmann, Master, Leading, \& Master, 2015). Penggunaan sabun menyebabkan peningkatan $\mathrm{Ph}$ kulit, menghilangkan kelembapan kulit, sehingga menyebabkan kulit menjadi kering (Schoonhoven et al., (2015).

Perawatan kebersihan bertujuan menjaga kebersihan pasien, menyegarkan mereka dan membuat mereka merasa nyaman, bisa membantu mengurangi bau badan, merangsang sirkulasi, menghilangkan keringat, dan mengurangi potensi infeksi. Memandikan tradisional dengan baskom dan air telah lama menjadi standar dalam memandikan pasien ditempat tidur, namun perawatan kebersihan di tempat tidur adalah dianggap sebagai beban kerja potensial pada perawat karena pekerjaannya melelahkan (Kato, Irwan, Aoki, \& Kimie Umeda, 2017). Metode memandikan dengan DBB menghilangkan penggunaan baskom / air yang telah diidentifikasi sebagai sumber potensial yang signifikan dari infeksi yang ditularkan melalui air dan baskom.

\section{STRATEGI PENCARIAN DAN KRITERIA SELEKSI ARTIKEL}

Pencarian dilakukan dengan

menggunakan database berikut : Pubmed, Google scholar, Proquest. Pubmed dengan keyword disposable bed bath OR prepacked single units OR bathing without water, traditional bed bath OR bathing with water 
basins OR bathing with soap kemudian ditambahkan patient, selanjutnya dilakukan penggabungan semua keyword dan tersisa 5 artikel. Pencarian berikutnya di Google scholar dengan keyword "Traditional bed bathing and Disposable Bed Bathing and patient", tahun pencarian dibatasi 2010-2017 ditemukan 6 artikel, pencarian di Science direct dengan kata kunci (patient) OR adult, (disposable bed bath) OR (prepacked single units), (traditional bed bath) OR bathing with water basins) yang semuanya digabungkan ditemukan 9 artikel sedangkan pencarian di Proquest dengan keyword "Traditional bed bathing and Disposable bed Baths" dengan filter tahun 2010-2017, ditemukan 15 artikel. Kemudian dilakukan analisis dan total artikel yang diinklusi yaitu 12 artikel.

\section{HASIL PENELITIAN}

Berdasarkan penelusuran $\begin{array}{r}\text { literatur } \\ \text { beberapa } \\ \text { yang dilakukan ditemukan membahas tentang }\end{array}$
penelitian yang memandikan
memandikan tradisional dan memandikan
dengan metode disposable bed baths (DBB).
Penelitian yang dilakukan oleh Gillis et al., (2015) yang bertujuan untuk membandingkan tingkat hidrasi kulit sebelum dan sesudah dimandikan dengan 2 metode memandikan yang berbeda yaitu metode memandidikan tradisional dan metode memandikan dengan menggunakan washlap mandi sekali pakai (disposable bed baths), penelitian melibatkan sampel 150 orang dengan membagi menjadi 2 kelompok, pengukuran dilakukan di tiga titik yaitu di pipi, kaki, dan tangan dengan menggunakan Mouisture Motor SC(Delfin Technologies LTD), pengukuran dilakukan selang waktu 3-7 jam setelah dimandikan, dan hasilnya hidrasi kulit lebih baik pada kelompok yang dimandikan dengan metode Disposable bed baths, utamanya pada bagian pipi.

Penelitian yang dilakukan oleh Schoonhoven et al., (2015) yang bertujuan untu membandingkan dua metode memandikan di tempat tidur yaitu memandikan tradisional dan DBB berdasarkan efek terhadap integritas kulit, dan biaya. Penelitian dilakukan di 56 panti jompo di Belanda dengan melibatkan 500 pasien dengan tingkat ketergantungan yang tinggi, pasien dibagi menjadi 2 kelompok yaitu kelompok kontrol (memandikan tradisional) dan kelompok intervensi (DBB). Semua kelompok dimandikan selama 6 minggu ditemukan hasil bahwa kelainan kulit / lesi dari waktu ke waktu sedikit menurun di kelompok intervensi (DBB), dan sedikit meningkat pada kelompok kontrol yaitu $72,7 \%$ dan $77,6 \%$, meskipun tidak signifikan secara statistik $(\mathrm{p}=0,04)$. Perbedaan signifikan ditemukan dari segi biaya, yaitu pada grup intervensi lebih membutuhkan biaya yang sedikit dibandingkan grup kontrol.

Penelitian yang dilakukan oleh Larsson et al., (2004) dengan tujuan membandingkan dua metode memandikan yaitu memandikan tradisional tradisional dengan DBB untuk menilai waktu memandikan, jumlah mikroba pada kulit, kepuasan perawat, dan biaya. Proses penelitian melibatkan 40 responden di Rumah Sakit Presbyterian New York, dilakukan selama 12 minggu dan didapatkan hasil ke dua metode memandikan sama-sama efektif menurunkan jumlah kuman, namun tidak terdapat perbedaan secara statistik, Dari segi durasi lebih cepat pada metode DBB, dan pilihan memandikan dengan DBB lebih disukai oleh perawat.

Penelitian yang dilakukan oleh Horstmann et al.,( 2015) pada 58 pasien yang dibagi menjadi 2 kelompok, dengan tujuan melihat durasi mandi, biaya mandi, kepuasan perawat dan kepuasan pasien pada kelompok kontrol(memandikan tradisional ) dan kelompok intervensi (DBB) didapatkan hasil secara signifikan lebih sedikit waktu digunakan pada metode DBB (p $<0,001)$, dalam hal biaya meskipun memandikan tradisional lebih tinggi 
dibanding DBB namun secara statistik tidak signifikan ( $p>0,05)$, kedua metode memandikan disukai oleh pasien, namun metode DBB lebih dipilih oleh $70 \%$ perawat.

TABEL 1: PENCARIAN PICOT

\begin{tabular}{|c|c|c|c|c|}
\hline Kata Kunci PICOT & 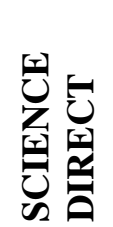 & 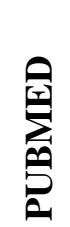 & 뒁 & 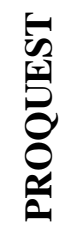 \\
\hline $\begin{array}{l}\text { "traditional bed bathing } \\
\text { "OR "conventional bed } \\
\text { baths" OR "bathing } \\
\text { with soap and water", } \\
\text { "modern bed bathing) } \\
\text { OR disposable use bed } \\
\text { bathing) OR washing } \\
\text { without water, } \\
\text { "Traditional bed bathing } \\
\text { and Disposable bed } \\
\text { Baths" }\end{array}$ & 2 & 9 & 8 & 15 \\
\hline
\end{tabular}

\section{ALGORITMA PENCARIAN}

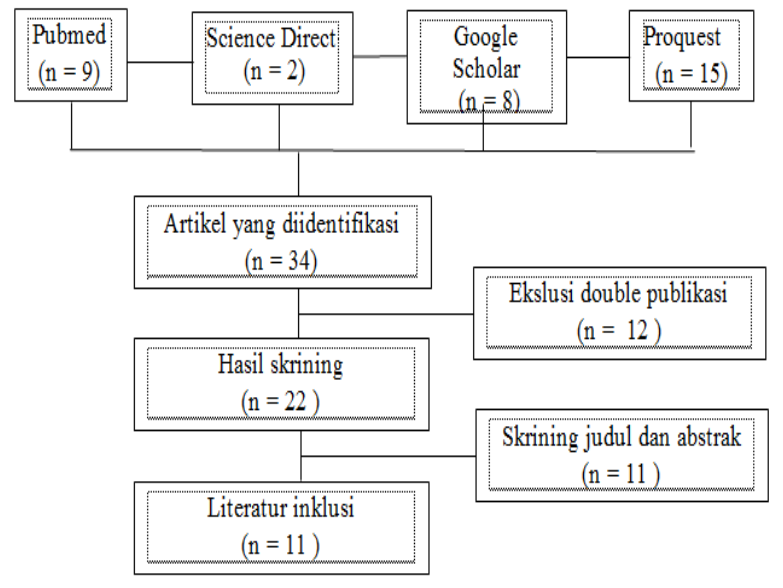

Gambar 1: Algoritma Pencarian 
Tabel 2: SYNTHESIS GRID

\begin{tabular}{|c|c|c|c|c|c|c|c|}
\hline No & Pengarang & Judul dan tahun & Responden & Tujuan & Metode Penelitian & Hasil & $\begin{array}{c}\text { Keterbatasan } \\
\text { Penelitian }\end{array}$ \\
\hline 1. & $\begin{array}{l}\text { Emily Toth } \\
\text { Martin; } \\
\text { Samran Haider } \\
\text {; } \\
\text { Maria } \\
\text { Palleschi ; } \\
\text { Sommer Eagle } \\
\text {; } \\
\text { Delfin V. } \\
\text { Crisostomo; } \\
\text { Pamela } \\
\text { Haddox ; } \\
\text { Laura Harmon } \\
\text {; } \\
\text { Robin Mazur ; } \\
\text { Judy Moshos; } \\
\text { Dror } \\
\text { Marchaim ; } \\
\text { Keith S. Kaye }\end{array}$ & $\begin{array}{l}\text { Bathing } \\
\text { hospitalized } \\
\text { dependent } \\
\text { patients with } \\
\text { prepackaged } \\
\text { disposable } \\
\text { washcloths } \\
\text { instead of } \\
\text { traditional bath } \\
\text { basins: } \\
\text { A case-crossover } \\
\text { study (2017) }\end{array}$ & $\begin{array}{l}2637 \\
\text { pasien di } \\
2 \text { rumah } \\
\text { sakit di } \\
\text { Detroit } \\
\text { dan } \\
\text { Michigan }\end{array}$ & $\begin{array}{l}\text { Mengkaji efek dari } \\
\text { penggunaan disposable } \\
\text { bed bathing sebagai } \\
\text { pengganti memandikan } \\
\text { menggunakan baskom } \\
\text { terhadap insiden HAIs } \\
\text { (Hospital Acquired } \\
\text { Infections) dan jumlah } \\
\text { kerusakan permukaan } \\
\text { kulit }\end{array}$ & $\begin{array}{l}\text { Penelitian prospektif } \\
\text { studi dengan intervensi. } \\
\text { Delapan bulan periode } \\
\text { intervensi, yaitu } \\
\text { memandikan } \\
\text { menggunakan } \\
\text { disposable bed bath } \\
\text { dibandingkan dengan } 8 \\
\text { bulan periode kontrol, } \\
\text { yaitu memandikan } \\
\text { menggunakan baskom. } \\
\text { Selama periode } \\
\text { tersebut, dilakukan } \\
\text { pengumpulan data } \\
\text { melalui rekam medis } \\
\text { pasien, integritas kulit } \\
\text { dievaluasi melalui } \\
\text { catatan perawat. }\end{array}$ & $\begin{array}{l}\text { Pada akhir penelitian, } \\
\text { ditemukan } 33 \text { insiden } \\
\text { adanya infeksi pada } \\
\text { pasien yang dirawat di } \\
\text { RS dengan perbedaan } \\
\text { yang dianggap tidak } \\
\text { bermakna antara grup } \\
\text { kontrol dan intervensi, } \\
\text { namun adanya } \\
\text { kerusakan integritas } \\
\text { kulit lebih sedikit pada } \\
\text { kelompok intervensi. }\end{array}$ & $\begin{array}{l}\text { 1. Jumlah sampel } \\
\text { penelitian yang } \\
\text { sedikit. } \\
\text { 2. penggunaan } \\
\text { pakaian yang dapat } \\
\text { menyebabkan bias } \\
\text { pada penelitian } \\
\text { yang berhubungan } \\
\text { dengan integritas } \\
\text { kulit }\end{array}$ \\
\hline 2. & $\begin{array}{l}\text { Lisette } \\
\text { Schoonhoven, } \\
\text { Betsie G.I. } \\
\text { van Gaal, } \\
\text { Steven } \\
\text { Teerenstra, } \\
\text { Eddy Adang, } \\
\text { Carine van } \\
\text { der Vleuten, } \\
\text { dan van } \\
\text { Theo Achterberg. }\end{array}$ & $\begin{array}{l}\text { Cost- } \\
\text { consequence } \\
\text { analysis of } \\
\text { "washing } \\
\text { without water", } \\
\text { for } \\
\text { nursing } \\
\text { home residents : } \\
\text { A cluster } \\
\text { randomized trial } \\
(2015)\end{array}$ & & $\begin{array}{l}500 \text { orang dewasa } \\
\text { yang dibagi menjadi } \\
\text { kelompok kontrol dan } \\
\text { kelompok intervensi }\end{array}$ & $\begin{array}{l}\text { Untuk membandingkan } \\
\text { dua metode } \\
\text { memandikan di tempat } \\
\text { tidur yaitu } \\
\text { memandikan tradisional } \\
\text { dan disposable bed } \\
\text { baths berdasarkan efek } \\
\text { terhadap integritas kulit, } \\
\text { dan biaya. }\end{array}$ & 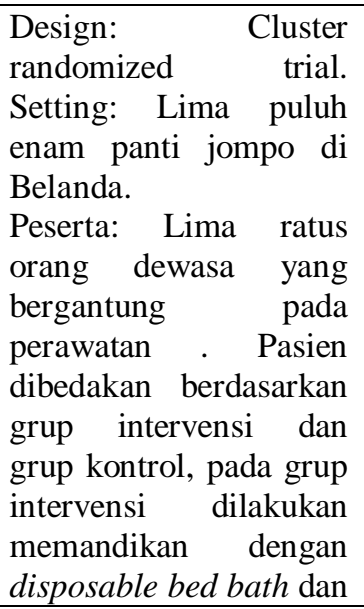 & $\begin{array}{l}\text { Kerusakan kulit atau } \\
\text { adanya lesi pada } \\
\text { kelompok intervensi } \\
\text { berkurang dan sedikit } \\
\text { meningkat pada } \\
\text { kelompok kontrol. } \\
\text { Tidak terdapat } \\
\text { perbedaan signifikan } \\
\text { berdasarkan } \\
\text { resistensi pasien. } \\
\text { Perbedaan signifikan } \\
\text { ditemukan dari segi } \\
\text { biaya, yaitu pada } \\
\text { grup intervensi lebih } \\
\text { membutuhkan }\end{array}$ \\
\hline
\end{tabular}




\begin{tabular}{|c|c|c|c|c|c|c|c|}
\hline & & & & & & $\begin{array}{lr}\text { grup } & \text { kontrol } \\
\text { menggunakan } & \text { baskom. } \\
\text { Dilakukan } & \text { selama } 6 \\
\text { minggu, } & \text { kemudian } \\
\text { dilakukan } & \text { penilaian } \\
\text { terhadap } & \text { adanya } \\
\text { kerusakan } & \text { integritas } \\
\text { kulit, dan } & \text { dari segi } \\
\text { biaya. } & \end{array}$ & $\begin{array}{lr}\text { biaya yang } & \text { sedikit } \\
\text { dibandingkan } & \text { grup } \\
\text { kontrol. } & \end{array}$ \\
\hline 3. & $\begin{array}{l}\text { Katrin Gillis, , } \\
\text { Inge Tency, } \\
\text { Ella Roelant, } \\
\text { Sarina } \\
\text { Laureys, } \\
\text { Hendrik } \\
\text { Devriendt , } \\
\text { Dirk Lips, }\end{array}$ & $\begin{array}{l}\text { Skin hydration in } \\
\text { nursing home } \\
\text { residents using } \\
\text { disposable bed } \\
\text { baths (2015) }\end{array}$ & & 150 orang & $\begin{array}{l}\text { membandingkan } \\
\text { tingkat hidrasi kulit } \\
\text { sebelum dan sesudah } \\
\text { dimandikan dengan } 2 \\
\text { metode memandikan } \\
\text { yang berbeda yaitu } \\
\text { metode memnadikan } \\
\text { tradisional dan DBB }\end{array}$ & $\begin{array}{l}\text { Penelitian } \\
\text { menggunakan metode } \\
\text { cluster Randomized } \\
\text { trial dan melibatkan } \\
\text { sampel } 150 \text { orang } \\
\text { dengan membagi } \\
\text { menjadi 2 kelompok, } \\
\text { pengukuran dilakukan } \\
\text { di tiga titik yaitu di } \\
\text { pipi, kaki, dan tangan } \\
\text { dengan menggunakan } \\
\text { Mouisture Motor } \\
\text { SC(Delfin a } \\
\text { Technologies LTD), } \\
\text { pengukuran dilakukan } \\
\text { selang waktu 3-7 jam } \\
\text { setelah dimandikan }\end{array}$ & \\
\hline 4. & $\begin{array}{l}\text { Lis } \\
\text { Horstmann } \\
\text { Nøddeskou, } \\
\text { Lars E. } \\
\text { Hemmingsen } \\
\text { dan } \\
\text { Britta } \\
\text { Hørdam }\end{array}$ & $\begin{array}{l}\text { Elderly patients' } \\
\text { and nurses' } \\
\text { assessment of } \\
\text { traditional bed } \\
\text { bath compared } \\
\text { to prepacked } \\
\text { single units - } \\
\text { randomised } \\
\text { controlled trial. } \\
\text { (2015) }\end{array}$ & 2015 & $\begin{array}{lr}58 \text { pasien yang dibagi } \\
\text { menjadi kelompok } \\
\text { kontrol dan } \\
\text { intervensi }\end{array}$ & $\begin{array}{l}\text { membandingkan } \\
\text { memandikan } \\
\text { tradisional } \\
\text { menggunakan baskom } \\
\text { dan menggunakan } \\
\text { disposable bed bath } \\
\text { dengan melihat } 4 \\
\text { faktor, yaitu durasi dan } \\
\text { kualitas memandikan, } \\
\text { biaya, kepuasan } \\
\text { perawatn dan kepuasan } \\
\text { pasien. }\end{array}$ & $\begin{array}{l}58 \text { pasien dimandikan } \\
\text { dengan dua metode } \\
\text { pada dua hari berturut- } \\
\text { turut, hari pertama } \\
\text { dengan memandikan } \\
\text { tradisional dan hari } \\
\text { kedua dengan } \\
\text { menggunakan DBB. } \\
\text { Observasi dilakukan } \\
\text { selama memandikan } \\
\text { dengan melihat } \\
\text { durasinya, penggunaan }\end{array}$ & $\begin{array}{c}\text { Kelemahan dari } \\
\text { penelitian ini adalah } \\
\text { hanya dilakukan pada } \\
\text { ruang interna dan ada } \\
\text { beberapa pasien tidak } \\
\text { dapat menjelaskan } \\
\text { dengan jelas pilihannya. }\end{array}$ \\
\hline
\end{tabular}




\begin{tabular}{|c|c|c|c|c|c|c|c|}
\hline & & & & & & $\begin{array}{ll}\text { alat-alat, } & \text { dan } \\
\text { kualitasnya. } & \end{array}$ & \\
\hline 5. & $\begin{array}{l}\text { Debra } \\
\text { Johnson; } \\
\text { Lauri } \\
\text { Lineweaver; } \\
\text { and } \\
\text { Lenora M. } \\
\text { Maze. }\end{array}$ & $\begin{array}{lr}\text { Patient's } & \text { Bath } \\
\text { Basins as a } & \\
\text { Potential } & \\
\text { Sources } \quad \text { Of } \\
\text { Infection : A } \\
\text { Multicenter } \\
\text { Sampling Study }\end{array}$ & 2009 & Meksiko & $\begin{array}{l}\text { Untuk mengidentifikasi } \\
\text { dan menghitung bakteri } \\
\text { pada baskom mandi } \\
\text { pasien }\end{array}$ & $\begin{array}{l}\text { Prospective study. } \\
\text { Dilakukan evaluasi } \\
\text { pada } 92 \text { baskom di } 3 \\
\text { ruang perawatan akut } \\
\text { RS yang telah } \\
\text { digunakan minimal dua } \\
\text { kali dalam } 48 \text { jam. } \\
\text { Metodenya yaitu } \\
\text { dengan melakukan } \\
\text { swab menggunakan } \\
\text { sponge pada seluruh } \\
\text { permukaan } \\
\text { baskom.Kemudian } \\
\text { sponge tersebut } \\
\text { dilakukan pemeriksaan } \\
\text { kultur. }\end{array}$ & 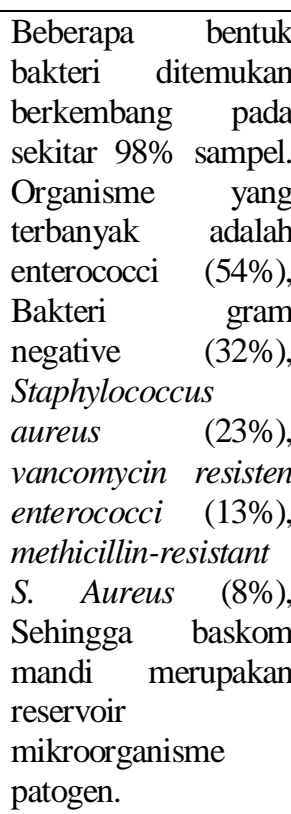 \\
\hline 6. & $\begin{array}{l}\text { Fiona M. ; } \\
\text { Judy } \\
\text { O'Sullivan ; } \\
\text { Nicola } \\
\text { Cadman }\end{array}$ & $\begin{array}{l}\text { The provision of } \\
\text { patient personal } \\
\text { hygiene in the } \\
\text { intensive } \\
\text { care unit: A } \\
\text { descriptive } \\
\text { exploratory } \\
\text { study } \\
\text { of bed-bathing } \\
\text { practice }\end{array}$ & 2011 & $\begin{array}{l}\text { Pada } 4 \text { ICU di } \\
\text { Australian } \\
\text { metropolitan } \\
\text { hospital. }\end{array}$ & \begin{tabular}{lr}
\multicolumn{2}{l}{ Untuk mendeskripsikan } \\
pekerjaan & sehari-hari \\
perawat & saat \\
melakukan & personal \\
hygiene pasien di ICU
\end{tabular} & $\begin{array}{lrr}\begin{array}{l}\text { Desain mix } \\
\text { metode }\end{array} & \begin{array}{r}\text { method, } \\
\text { pertama }\end{array} \\
\text { menggunakan } & \\
\text { kuesioner } & \text { dan } & \text { metode } \\
\text { kedua } & & \text { dengan } \\
\text { melakukan } & \text { Focus } \\
\text { Group } & \text { Discussion } \\
\text { (FGD). } & & \end{array}$ & $\begin{array}{l}\text { Gambaran } \\
\text { pelaksanaan } \\
\text { personal hygiene } \\
\text { pasien di ICU } \\
\text { berdasarkan } \\
\text { kuesioner adalah } \\
\text { terdapat } \\
\text { pasien y,7\% } \\
\text { terventilasi yang } \\
\text { mekanik, dilakukan } \\
\text { sekitar 15-30 menit, } \\
\text { penggunaan sabun } \\
\text { dan air } 71 \% \text {, } \\
\text { clorhexidin } \\
(16,1 \%), \\
\text { disposable bed bath } \\
12,2 \% \text {. }\end{array}$ \\
\hline
\end{tabular}




\begin{tabular}{|c|c|c|c|c|c|c|c|}
\hline 7. & $\begin{array}{c}\text { Marchaim, D., } \\
\text { Taylor, A. R., } \\
\text { Hayakawa, K., } \\
\text { Bheemreddy, S., } \\
\text { Sunkara, B., } \\
\text { Moshos, J., ... } \\
\text { Kaye, K. S. }\end{array}$ & $\begin{array}{l}\text { Hospital bath } \\
\text { basins are } \\
\text { frequently } \\
\text { contaminated } \\
\text { with multidrug- } \\
\text { resistant human } \\
\text { pathogens }\end{array}$ & & $\begin{array}{l}\text { Pada } 88 \text { rumah sakit di } \\
\text { Amerika Serikat dan } \\
\text { Kanada }\end{array}$ & $\begin{array}{l}\text { Untuk melihat infeksi } \\
\text { pada baskom mandi di } \\
88 \text { rumah sakit }\end{array}$ & $\begin{array}{lr}\text { Desain } & \text { prosfective, } \\
\text { dengan menggunakan } \\
\text { kultur pada baskom, } \\
\text { sebelum } & \text { digunakan } \\
\text { untuk } & \text { memandikan } \\
\text { pasien. } & \end{array}$ & $\begin{array}{lr}686 \text { baskom } & \text { dari } \\
\text { berbagai Rumah } & \text { Sakit } \\
\text { yang dilakukan } & \text { uji, } \\
\text { sebanyak } & 62,2 \% \\
\text { terkontaminasi } & \text { dengan } \\
\text { satu atau lebih } \\
\text { mikroorganisme } \\
\text { patogen studi . }\end{array}$ \\
\hline 8. & $\begin{array}{l}\text { Larson, B. E. L., } \\
\text { Ciliberti, T., } \\
\text { Chantler, C., } \\
\text { Abraham, J., } \\
\text { Lazaro, E. M., } \\
\text { Venturanza }\end{array}$ & $\begin{array}{l}\text { Comparison of } \\
\text { tradisional and } \\
\text { disposable bed } \\
\text { baths in critically } \\
\text { ill patients }\end{array}$ & 2004 & $\begin{array}{l}40 \text { pasien di di ruang ICU } \\
\text { di } 3 \text { rumah sakit di } \\
\text { Amerika Serikat }\end{array}$ & $\begin{array}{l}\text { Untuk melihat jumlah } \\
\text { mikroorganisme sebelum } \\
\text { dan sesudah dimadikan } \\
\text { dengan metode tradisional } \\
\text { dan disposable bed baths }\end{array}$ & Cross-over trial & $\begin{array}{lrr}\text { Dari } 40 & \text { pasien } & \text { yang } \\
\text { dibagi } & \text { atas } & 2 \\
\text { kelompok, responden } \\
\text { yang } & \text { dimandikan } \\
\text { dengan } & \text { metode } & \text { DBB } \\
\text { lebih menurun } & \text { jumlah } \\
\text { mikroorganisme } & \text { nya } \\
\text { setelah } & \text { dimandikan } \\
\text { dibandinakan } & \text { dengan } \\
\text { kelompok } & \text { yang } \\
\text { dimndikan } & \text { secara } \\
\text { tradisional } & \end{array}$ \\
\hline
\end{tabular}




\section{PEMBAHASAN}

Meskipun memandikan tradisional dapat menurunkan jumlah mikroorganisme di kulit seperti penelitian yang dilakukan oleh Larson et al.,( 2004) namun memandikan pasien dengan cara tradisional yaitu menggunakan baskom mandi mengandung banyak kelemahan,menurut beberapa penelitian yaitu baskom mandi yang digunakan terbukti sebagai reservoir mikroorganisme patogen. Penelitian yang dilakukan oleh Marchaim et al., (2012) bahwa baskom mandi yang biasa digunakan untuk perawatan pasien di ICU, bangsal bedah medis, dan bangsal pasien biasa memiliki peran sebagai reservoir mikroorganisme patogen diberbagai rumah sakit. 686 baskom dari berbagai Rumah Sakit yang dilakukan uji, sebanyak $62,2 \%$ terkontaminasi dengan satu atau lebih mikroorganisme patogen studi . Bakteri gram negatif adalah jenis bakteri yang paling sering terisolasi, diikuti oleh Enterococci dan Staphilococcus Aureus. Penelitian ini sejalan dengan penelitian yang dilakukan oleh Johnson, Lineweaver, \& Maze( 2009) bahwa baskom mandi terkontaminasi minroorganisme patogen sampai $98 \%$.

Penggunaan sabun dan air yang dikombinasikan dengan pengeringan menggunakan handuk kering pada memandikan tradisional dapat meningkatkan pH kulit, menghilangkan minyak kulit alami, menyebabkan kekeringan kulit dan penurunan resistensi terhadap invasi mikroba (Gray et al., 2012). Penggunaan sabun dan air hangat pada orang tua sebaiknya dihindari karena bisa menyebabkan kulit kering dan rusak, jika kulit lansia sangat kering maka direkomendasikan sabun hanya digunakan di daerah aksila, genitalia dan kaki (Cowdell \& Steventon, 2013). Disamping itu memandikan, utamanya memandikan tradisional bisa menyebabkan beban kerja potensial pada perawat karena pekerjaannya melelahkan, adanya nyeri punggung, gangguan pada muskoloskeletal karena aktivitas berat, berulang-ulang, menyiapkan air menyebabkan kelelahan dan berdampak pada beban kerja perawat(Kato et al., 2017); (Dougherty et al., 2010)

Penggunaan metode memandikan Disposable Bed Baths(DBB) masih sangat rendah dibandingkan dengan memandikan tradisional sebagaimana penelitian yang dilakukan oleh Coyer et al., (2011) yaitu hanya $12,2 \%$ dibanding memnadikan tradisional yaitu $71 \%$,padahal memandikan dengan metode DBB sebagai alternatif memandikan tradisional(Thoma-lürken, Bleijlevens, Lexis, Hamers, \& Witte, 2015) mengandung banyak manfaat yaitu dapat menurunkan jumlah mikroorganisme di kulit (Horstmann et al., 2015), beberapa produk DBB mengandung anti mikroba seperti Polyhexamethylene Biguanide (PHMB) dimana PHMB membunuh interaksi MRSA via intraselular langsung dengan patogen di dalam keratinosit dan sel inang(Kamaruzzaman, Firdessa, \& Good, 2015);(Creppy, Diallo, Moukha, \& Eklugadegbeku, 2014).

Memandikan dengan metode DBB menyebabkan integritas kulit lebih baik dibanding memandikan tradisional(Schoonhoven et al., 2015), dari segi biaya dan durasi memandikan juga lebih rendah pada kelompok memandikan DBB, serta kepuasan perawat juga lebih tinggi pada kelompok memandikan dengan metode DBB(Larson et al., 2004), memandikan DBB menghinagkan pengguanaan baskom, air da sabun(Collins \& Hampton, 2003)

\section{KESIMPULAN}

Memandikan dengan cara tradisional masih banyak digunakan diberbagai rumah sakit, meskipun memandikan tradisional dari berbagai penelitian menyebabkan kulit menjadi kering, baskom mandi yang digunakan banyak mengandung mikroorganisme patogen dan menyebakan 
kelelahan pada perawat karena panjangnya durasi waktu yang digunakan. Metode mandi dengan menggunakan kantong mandi sekali pakai banyak menghemat waktu perawat karena tidak lagi memerlukan pembilasan dengan menggunakan sabun dan air, dan juga menghilangkan penggunaan baskom. Masih sedikit penelitian tentang perbandingan memandikan tradisional dan disposable bed baths kaitannya dengan biaya, durasi dan jumlah mikroorganisme khususnya pasien yang dirawat di ruang ICU.

\section{DAFTAR PUSTAKA}

Bulechek, G. M., Butcher, H. K., Dochterman, J. M., \& Wagner, C. M. (2013). Nursing Intervention Classification (NIC). (6 edition). Mosby, St Louis.: ELSEVIER.

Collins, F., \& Hampton, S. (2003). A new concept in patient hygiene. British Journal of Nursing.

Cowdell, F., \& Steventon, K. (2013). Skin cleansing practices for older people : a systematic review. International Journal of Older People Nursing, 1-11. http://doi.org/10.1111/opn.12041

Coyer, F. M., Sullivan, J. O., Gradcert, \& Nicola Cadman. (2011). The provision of patient personal hygiene in the intensive care unit: A descriptive exploratory study of bed-bathing practice. Elsevier, 198-209.

http://doi.org/10.1016/j.aucc.2010.08.00 1

Creppy, E. E., Diallo, A., Moukha, S., \& Eklu-gadegbeku, C. (2014). Study of Epigenetic Properties of Poly ( HexaMethylene Biguanide ) Hydrochloride ( PHMB ). International Journal of Environmental Research and Public Health, 8069-8092.

http://doi.org/10.3390/ijerph110808069 Dougherty, L., Fergusson, D., Francis, C.,
Iggulden, H., Jevon, P., Moffatt, C., \& Martin, R. (2010). Personal Hygiene Care. IOWA: Wiley-Bickwell.

Gray, M., Beeckman, D., Bliss, D. Z., Fader, M., Junkin, J., Selekof, J., ... Logan, S. (2012). Incontinence-Associated Dermatitis : A Comprehensive Review and Update. Journal Wound, Ostomy and Continence Nurses Society., 39(February), 61-74. http://doi.org/10.1097/WON.0b013e318 $23 \mathrm{fe} 246$

Horstmann, L., Master, N., Leading, N., \&

Master, L. E. H. (2015). Elderly patients ' and nurses' assessment of traditional bed bath compared to prepacked single units - randomised controlled trial. Scandinavian Journal of Caring Sciences. http://doi.org/10.1111/scs.12170

Johnson, B. D., Lineweaver, L., \& Maze, L. M. (2009a). Patient's Bath Basins as a Potential Sources Of Infection : A Multicenter Sampling Study, 18(1), 3140. http://doi.org/10.4037/ajcc2009968

Johnson, B. D., Lineweaver, L., \& Maze, L. M. (2009b). Patient's Bath Basins As Potential Sources of Infection : A Multicenter Sampling Study. American Association of Critical Care Nurses, 18(1), 31-40. http://doi.org/10.4037/ajcc2009968

Kamaruzzaman, N. F., Firdessa, R., \& Good, L. (2015). Bactericidal effects of polyhexamethylene biguanide against intracellular Staphylococcus aureus EMRSA-15 and USA 300. Jurnal Antimicrobial Chemotherapy, 1-8. http://doi.org/10.1093/jac/dkv474

Kato, M., Irwan, A. M., Aoki, H., \& Kimie Umeda. (2017). Problem Identification of and Proposed Device Modification for Bedside Hygiene Care. International Journal of Caring Sciences, 10(2), 1052-1069.

Larson, B. E. L., Ciliberti, T., Chantler, C., 
Abraham, J., Lazaro, E. M., Venturanza, M., ... Zielhuis, G. A. (2004).

COMPARISON OF TRADITIONAL AND DISPOSABLE BED BATHS IN CRITICALLY ILL PATIENTS. AMERICAN JOURNAL OF CRITICAL $C A R E, 13(3), 235-242$. Retrieved from http://ajcc.aacnjournals.org/

Marchaim, D., Taylor, A. R., Hayakawa, K., Bheemreddy, S., Sunkara, B., Moshos, J., ... Kaye, K. S. (2012). American Journal of Infection Control Hospital bath basins are frequently contaminated with multidrug-resistant human pathogens. American Journal of Infection Control, 40(6), 562-564. http://doi.org/10.1016/j.ajic.2011.07.014

Noto, M. J., Domenico, H. J., Byrne, D. W., Talbot, T., Rice, T. W., Bernard, G. R., \& Wheeler, A. P. (2015). Chlorhexidine Bathing and Health Care - Associated Infections, 313(4), 369-378. http://doi.org/10.1001/jama.2014.18400

Schoonhoven, L., Gaal, B. G. I. Van, Teerenstra, S., Adang, E., Vleuten, C. Van Der, \& Achterberg, T. Van. (2015). Cost-consequence analysis of "“" washing without water " for nursing home residents : A cluster randomized trial §. International Journal of Nursing Studies, 52(1), 112-120.

http://doi.org/10.1016/j.ijnurstu.2014.08 .001

Thoma-lürken, T., Bleijlevens, M. H. C., Lexis, M. A. S., Hamers, J. P. H., \& Witte, L. P. De. (2015). An Overview of Potential Labor-Saving and QualityImproving Innovations in Long-Term Care for Older People. Journal of the American Medical Directors Association. http://doi.org/10.1016/j.jamda.2014.12.0 17

Toth, E., Mph, M., Haider, S., Dnp, M. P., Rn, S. E., Gnp-bc, R. M., ... Kaye, K. S. (2017). disposable washcloths instead of traditional bath basins : AJIC: American Journal of Infection Control. http://doi.org/10.1016/j.ajic.2017.03.023 Whiteley, S. M., Bodenham, A., \& Bellamy, M. C. (2006). Intensive Care. Churchill: Elsevier. 